\title{
Peningkatan kompetensi pedagogik guru melalui pelatihan perangkat pembelajaran abad-21 berbasis merdeka belajar di Kabupaten Pelalawan Riau
}

\author{
Ahmal*, Supentri, Piki Setri Pernantah, \& Mirza Hardian \\ Fakultas Keguruan dan Ilmu Pendidikan, Universitas Riau \\ *ahmal.ur81@gmail.com
}

\begin{abstract}
Abstrak. Perbaikan kualitas pendidikan dan pengajaran merupakan suatu keharusan dan mutlak bagi semua elemen pendidikan di negeri ini tidak kecuali seorang guru. Guru yang baik adalah guru yang mengerti dan memahami akan tugas dan kewajibannya. Guru merupakan the key actor in the learning. Guru harus mengikuti trend pembelajaran yang relevan dengan kondisi saat ini yakni pembelajaran abad 21. Untuk mengembangkan pembelajaran abad 21 berbasis merdeka belajar, guru harus melaksanakan pembelajaran yang bersifat student-center. Perangkat pembelajaran yang dikembangkan harus memiliki prinsip efisiensi, efektifitas, dan berorientasi pada peserta didik. Hal itu dilakukan dengan mempertimbangkan kesiapan, ketertarikan, dan kebutuhan belajar peserta didik di kelas sehingga dapat mencapai tujuan pembelajaran dan tujuan pendidikan nasional secara maksimal. Kegiatan pengabdian kepada masyarakat ini diterapkan dengan metode workshop selama 3 (tiga) hari dengan pembicara oleh para dosen yang sesuai dengan bidang keahliannya dan bekerjasama dengan organisasi FOGIPSI. Kegiatan pengabdian ini telah memberikan pemahaman, bimbingan, dan pengalaman bagi guru-guru se-Kabupaten Pelalawan terkait dengan penyusunan perangkat pembelajaran abad 21 berbasis merdeka belajar yang relevan dengan era revolusi industri 4.0 saat ini sehingga dapat diterapkan oleh para guru pada saat bertugas menjalankan profesi di sekolah.
\end{abstract}

Kata kunci: kompetensi pedagogik guru, perangkat pembelajaran abad 21, merdeka belajar

\begin{abstract}
Improving the quality of education and teaching is a must and absolutely for all elements of education in this country, not except for a teacher. Good teachers are teachers who understand and understand their responsibilities and obligations. The teacher is the key actor in the learning. Teachers must follow learning trends that are relevant to current conditions, namely 21 st century learning. To develop 21 st century learning based on "merdeka belajar", teachers must carry out student-center learning. The learning tools developed must have the principles of efficiency, effectiveness, and be learner-oriented. This is done by considering the readiness, interest and learning needs of students in the classroom so that they can achieve maximum learning goals and national education goals. This community service activity is implemented using a workshop method for 3 (three) days with speakers by lecturers according to their fields of expertise and in collaboration with the FOGIPSI organization. This event seeks to provide understanding, guidance, and experience for teachers in Pelalawan Regency related to 21 st century learning tools based on "merdeka belajar" that are relevant to the current era of the industrial revolution 4.0.
\end{abstract}

Keywords: teacher pedagogic competence, 21st century learning tools, "merdeka belajar"

To cite this article: Ahmal., Supentri., P. S. Pernantah., \& M. Hardian. 2020. Peningkatan kompetensi pedagogik guru melalui pelatihan perangkat pembelajaran abad-21 berbasis merdeka belajar di Kabupaten Pelalawan Riau. Unri Conference Series: Community Engagement 2: 432-439. https://doi.org/10.31258/unricsce.2.432-439

(C) 2020 Authors

Peer-review under responsibility of the organizing committee of Seminar Nasional Pemberdayaan Masyarakat 2020 


\section{PENDAHULUAN}

Undang-Undang No. 20 Tahun 2003 tentang Sistem Pendidikan Nasional menyatakan bahwa pendidikan adalah usaha sadar dan terencana untuk mewujudkan suasana belajar dan proses pembelajaran agar peserta didik secara aktif mengembangkan potensi dirinya untuk memiliki kekuatan spiritual keagamaan, pengendalian diri, kepribadian, kecerdasan, akhlak mulia, serta keterampilan yang diperlukan dirinya, masyarakat, bangsa dan negara. Sehingga pendidikan merupakan faktor utama dalam pembentukan pribadi manusia sekaligus warga negara. Pendidikan juga sangat berperan dalam membentuk baik atau buruknya karakter manusia menurut ukuran normatif. Menyadari akan pentingnya pendidikan tersebut, pemerintah harus sangat serius menangani masalah bidang pendidikan, karena dengan sistem pendidikan yang baik diharapkan muncul generasi penerus bangsa yang berkualitas dan mampu menyesuaikan diri untuk hidup bermasyarakat, berbangsa dan bernegara.

Perbaikan kualitas pendidikan dan pengajaran merupakan suatu keharusan dan mutlak bagi semua elemen pendidikan di negeri ini tidak kecuali seorang guru, guru yang baik adalah guru yang mengerti dan memahami akan tugas dan kewajibannya. Guru merupakan the key actor in the learning. Dalam hal ini guru memiliki peran yang sangat vital dan fundamental dalam membimbing, mengarahkan, dan mendidik siswa dalam proses pembelajaran. Guru berperan sangat penting karena sebaik apapun kurikulum dan sistem pendidikan yang ada, tanpa didukung mutu guru yang memenuhi syarat maka semuanya akan sia-sia. Sebaliknya, dengan guru yang bermutu maka kurikulum dan sistem yang tidak baik akan tertopang. Sehingga guru juga harus memperhatikan standar proses pembelajaran, karena melalui standar proses pendidikan setiap guru dapat menentukan bagaimana seharusnya proses pembelajaran dilaksanakan dan menangani setiap permasalahan yang ditimbulkan di saat proses pembelajaran berlangsung sekaligus guru juga harus mengikuti perkembangan pendidikan di Indonesia saat ini. Salah satu aksi yang bisa dilakukan guru melalui pengembangan perangkat pembelajaran sesuai dengan arahan kurikulum dan Kemendikbud saat ini yang berbasis pembelajaran abad 21 (revolusi Industri 4.0) dengan paradigma merdeka belajar.

Dunia pendidikan ditantang untuk menemukan cara bagaimana dunia pendidikan sukses dalam pekerjaan dan kehidupan melalui penguasaan keterampilan berpikir kreatif, pemecahan masalah yang fleksibel, berkolaborasi dan berinovasi yang relevan dengan abad 21. Beberapa sumber seperti Trilling \& Fadel (2009), Ledward \& Hirata (2011), Partnership for 21Century Learning; National Science Foundation, Educational Testing Services, NCREL, Metiri Group, Pacific Policy Research Center, dan lainnya menunjukkan pentingnya penguasaan keterampilan abad ke-21 untuk untuk mencapai transformasi yang diperlukan. Berkaitan dengan tantangan pendidikan di Indonesia adalah adanya konsep Merdeka Belajar yang merupakan kebijakan baru Kementerian Pendidikan dan Kebudayaan Republik Indonesia (Kemendikbud RI) yang dicanangkan oleh Mendikbud Nadiem Anwar Makarim. Nadiem Makarim menyebutkan merdeka belajar merupakan kemerdekaan berfikir (Yamin \& Syahrir, 2020). Esensi kemerdekaan berpikir, menurut Nadiem, harus didahului oleh para guru sebelum mereka mengajarkannya pada peserta didik (Mustaghfiroh, 2020). Sehingga perlu adanya penguatan kompetensi dan keterampilan guru untuk menghadapi kemajuan pendidikan di Indonesia.

Keterampilan penting yang dikuasai guru masa depan dalam menghadapi pendidikan abad 21 adalah digital age literacy, inventive thinking, effective communication, dan high productivity. Guru yang cerdas akan mampu berfikir kritis dalam memecahkan masalah serta kreatif dan inovatif dalam bekerja. Jika kompetensi tersebut disertai dengan kemampuan berkomunikasi efektif dan mampu bekerja sama dengan orang lain, maka tantangan terberat apapun mampu dilalui guru. Guru juga harus mengikuti trend pembelajaran yang relevan dengan kondisi saat ini sehingga harus menyiapkan rencana pembelajaran yang relevan dengan kondisi sekarang.

Pada tahap perencanaan pembelajaran, para guru di semua satuan pendidikan wajib menyusun Rencana Pelaksanaan Pembelajaran (RPP) yang lengkap dan sistematis agar pembelajaran dapat berlangsung secara interaktif, inspiratif, menyenangkan, menantang, dan memotivasi seluruh peserta didik berpartisipasi aktif, serta memberikan kesempatan yang memadai prakarsa, kreativitas, dan kemandirian para peserta didik sesuai dengan bakat, minat, dan perkembangan fisik serta psikologis mereka masing-masing (Rukayah, 2018).

Berdasarkan Surat Edaran Nomor 14 tahun 2019 Tentang Penyederhanaan Rencana Pelaksanaan Pembelajaran. Pada Akhir tahun 2019 tepatnya di bulan Desember, penyusunan RPP kembali berubah dimana Penyusunan RPP cukup berisikan tiga komponen inti, yakni tujuan pembelajaran, kegiatan pembelajaran, dan asesmen atau penilaian pembelajaran. RPP dibuat lebih sederhana, dan disusun harus memiliki prinsip efisien, efektif, dan berorientasi pada siswa. Penulisan RPP dilakukan dengan efisien dan efektif sehingga guru 
memiliki lebih banyak waktu untuk mempersiapkan dan mengevaluasi proses pembelajaran itu sendiri. Satu halaman saja cukup, yang juga merupakan salah satu dari empat pokok kebijakan baru "merdeka belajar" dari Kemendikbud RI. Melalui penyederhanaan administrasi, diharapkan waktu guru yang tersita untuk proses pembuatan administrasi dapat dialihkan untuk kegiatan belajar dan peningkatan kompetensi (Kemendikbud, 2019). Selain RPP, perangkat pembelajaran pendukung lainnya tentu harus diarahkan pula pada paradigma merdeka belajar agar saling mendukung satu sama lain dan relevan dengan pembelajaran abad 21 yang berbasis revolusi industri (4.0).

Untuk mengembangkan pembelajaran abad 21, guru harus memulai satu langkah perubahan yaitu merubah pola pembelajaran tradisional yang berpusat pada guru menjadi pola pembelajaran yang berpusat pada siswa. Perangkat pembelajaran abad 21 berbasis merdeka belajar ini memegang prinsip efisiensi, efektifitas, dan berorientasi pada peserta didik dengan mempertimbangkan kesiapan, ketertarikan, dan kebutuhan belajar peserta didik di kelas sehingga dapat mencapai tujuan pembelajaran dan tujuan pendidikan nasional secara maksimal.

Oleh sebab itu, perlu adanya perubahan paradigma berpikir demikian, sosialisasi, dan pelatihan kepada guru-guru terkait perubahan perangkat pembelajaran abad 21 berbasis merdeka belajar tersebut. Guru akan dibekali secara teoritis sekaligus praktek tentang perangkat pembelajaran abad 21 berbasis merdeka belajar. Diharapkan melalui pengabdian ini dapat meningkatkan pemahaman guru tentang perangkat pembelajaran abad 21 berbasis merdeka belajar dan dapat dilaksanakan sebagai salah satu tugasnya dalam kegiatan pengembangan profesi dan pembelajaran di sekolah.

Diperlukannya suatu pelatihan pendidikan yang disesuaikan dengan kurikulum merdeka belajar agar tujuan pembelajaran yang efektif dan efisien dapat terbangun dengan baik. Hal ini dapat kita perhatikan kutipan sebagai berikut; bahwa tanpa bangsa yang cerdas tidak mungkin bangsa itu ikut serta dalam persaingan pada global (Tilaar, 1998). Demikianlah dari dasar dan latar belakang ini, kegiatan ini untuk meningkatkan kompetensi guru melalui pelatihan perangkat pembelajaran berbasis abad 21 untuk menjawab tantangan zaman yang semakin kompetitif.

\section{METODE PENERAPAN}

Untuk memperoleh manfaat dari pengabdian ini metode penerapan yang telah dilakukan adalah dengan metode workshop yang dilaksanakan selama 3 (tiga) hari pada tanggal 03 Juli 2020, 10 Juli 2020, dan 27 Juli 2020. Kegiatan pelatihan ini didampingi oleh 6 (enam) narasumber (kolaborasi Tim Dosen bekerjasama dengan FOGIPSI) dan para peserta yang dibimbing langsung untuk memahami dan merancang perangkat pembelajaran abad 21 berbasis merdeka belajar yang sesuai dengan kurikulum 2013 sehingga para guru menghasilkan produk berupa perangkat pembelajaran abad 21 sesuai bidang studi masing-masing dengan paradigma merdeka belajar dan revolusi industri (4.0).

Penyelenggaraan kegiatan ini telah dilaksanakan selama 3 (tiga) hari, pada tahap pertama dan kedua dilaksanakan melalui Zoom Meeting mengingat adanya pandemic COVID-19. Sedangkan tempat pelaksanaan tahap ketiga ini akan dilaksanakan di SMAN 1 Pangkalan Kuras, Kabupaten Pelalawan, Riau dengan memperhatikan protokol kesehatan di masa pandemi ini. Berikut susunan jadwal pengabdian kepada masyarakat yang telah dilaksanakan, yaitu:

Tabel 1. Susunan Pelaksanaan Kegiatan

\begin{tabular}{lcll}
\hline Sesi & Hari/Tanggal & Waktu & \multicolumn{1}{c}{ Materi } \\
\hline $1 \quad$ Jum'at/ 03 Juli 2020 & $12.30-13.00$ & Registrasi \& Pembukaan \\
$13.00-14.00$ & $\begin{array}{l}\text { Teknik Menyusun RPP Abad 21 Berbasis Merdeka } \\
\text { Belajar }\end{array}$ \\
& $14.00-15.00$ & Menyusun Bahan Ajar Berbasis Merdeka Belajar \\
$15.00-16.00$ & Media Pembelajaran Berbasis Merdeka Belajar \\
$16.00-16.30$ & Diskusi \& Tanya Jawab
\end{tabular}




\begin{tabular}{ccll}
\hline Sesi & Hari/Tanggal & Waktu & \\
\hline 2 Jum'at/ 10 Juli 2020 & $12.30-13.00$ & Registrasi \& Pembukaan \\
& $13.00-14.00$ & Teknik Menyusun LKPD Berbasis Merdeka Belajar \\
$14.00-15.00$ & Penilaian Pembelajaran Berbasis Merdeka Belajar \\
& $15.00-16.00$ & Hybrid Learning di era Merdeka Belajar \\
& $16.00-16.30$ & Diskusi \& Tanya Jawab \\
& $08.00-08.30$ & Registrasi Peserta \\
& $08.30-10.00$ & Presentasi Kinerja (RPP Abad 21) \\
& $10.00-10.30$ & Coffee Break \\
& $10.30-12.00$ & Presentasi Kinerja (Bahan Ajar \& LKPD) \\
& $12.00-13.30$ & Ishoma \\
& $13.30-15.30$ & Presentasi Kinerja (Media pembelajaran \& Penilaian) \\
& $15.00-15.30$ & Diskusi \& Tanya Jawab \\
$15.30-16.00$ & Isho \\
$16.00-16.30$ & Refleksi dan Evaluasi Pelaksanaan Kegiatan PKM \\
& $16.30-17.00$ & Penutupan + Pembagian Sertifikat \\
\hline & &
\end{tabular}

Berdasarkan tabel 1, maka dapat dipahami bahwa kegiatan ini diselesaikan dengan format Webinar dan Pelatihan langsung di lapangan sehingga kegiatan ini tidak hanya sekedar memberikan wawasan tentang perangkat pembelajaran tetapi juga ada praktik dan penugasan yang dikerjakan oleh setiap peserta pengabdian. Kegiatan pengabdian ini juga terintegrasi dengan kegiatan Kukerta mahasiswa UNRI, peserta berperan aktif dan mendukung penuh kegiatan pengabdian dosen ini. Dengan adanya format webinar materi dan pelatihan langsung di lapangan maka di masa pandemic saat ini sudah sangat membantu guru dalam meningkatkan kemampuan pedagogiknya dalam menyusun perangkat pembelajaran. Ketercapaian target juga dapat dilihat dengan dihadirkannya salah satu guru sebagai narasumber yang juga sudah biasa memberikan pelatihan perangkat pembelajaran dan memahami terkait dengan perangkat pembelajaran merdeka belajar. Hal ini menyebabkan para peserta juga mendapatkan input dan materi dari para praktisi guru yang secara langsung juga mempraktikkan hal tersebut.

\section{HASIL DAN KETERCAPAIAN SASARAN}

Hasil pengabdian yang telah dilaksanakan didapatkan bahwa guru-guru di Kabupaten Pelalawan sangat antusias dan aktif dalam proses kegiatan webinar dan mampu menyusun/merancang perangkat pembelajaran abad 21 berbasis merdeka belajar yang ditugaskan sebagai bentuk usaha para guru dalam memulai semangat perubahan dan perbaikan pembelajaran di sekolah. Motivasi terbesar dari pengabdi adalah mampu memberikan dan membagikan ilmu (sharing knowledge) yang dimiliki sehingga dapat membantu meningkatkan wawasan guru dan mengatasi permasalahan yang sering timbul di dalam proses pendidikan di sekolah. Adapun hasil pengabdian yang telah dilaksanakan akan dirangkum ke dalam poin-poin berikut ini:

1. Berdasarkan materi pelatihan yang diberikan, para peserta pengabdian memahami maksud dari tujuan pengabdian ini. Satu materi yang diberikan memang tidak memiliki keterkaitan secara langsung, tetapi dapat menambah pengetahuan para peserta terkait dengan Hybrid Learning. 
2. Adanya hubungan timbal balik antara pengabdi dengan peserta dalam bentuk tanya jawab dan diskusi, sehingga sangat diyakini bahwa pengabdian ini dapat membantu para peserta dalam mengembangkan kompetensi pedagogik guru dan peningkatan kualitas pembelajaran di sekolah.

3. Target dari keikutsertaan para peserta guru di Kabupaten Pelalawan Riau sudah terpenuhi dan menunjukan antusiasme dari para peserta meskipun di tengah masa pandemik dan sebagian kegiatan dilaksanakan juga dengan proses daring (online).

4. Dari sekian banyak satuan pendidikan, artinya juga banyak guru di kabupaten Pelalawan, Riau. Berdasarkan hasil survey awal, belum ada pelatihan perangkat pembelajaran abad 21 berbasis merdeka belajar yang diadakan di kabupaten Pelalawan. Untuk itu, pengabdian kepada masyarakat ini sangat dibutuhkan oleh guru-guru se-Kabupaten Pelalawan.

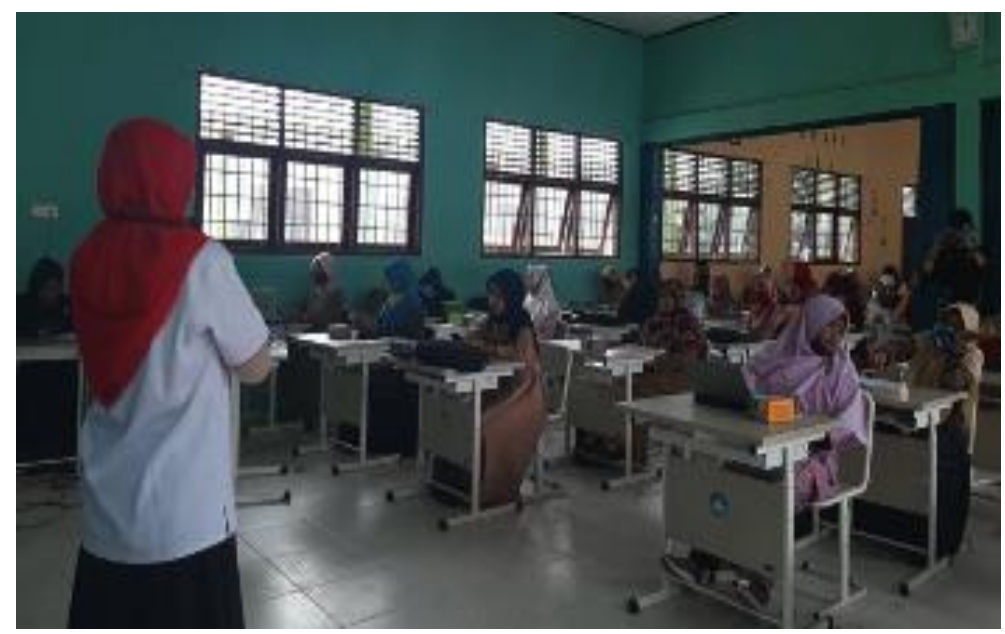

Gambar 1. Narasumber memberikan materi dan praktik langsung

Guru yang baik dan profesional adalah mampu mengaktualisasikan kompetensi dirinya sebagai guru secara baik, salah satunya adalah kompetensi pedagogik. Salah satu poin terpenting dalam kompetensi pedagogik ialah penyusunan rencana pembelajaran (Planning) yang merupakan salah satu fungsi utama yang harus dilakukan oleh seorang guru dalam melaksanakan proses pembelajaran (Dego, dkk, 2019). Kompetensi pedagogik merupakan kompetensi pengelolaan pembelajaran yang dapat dilihat dari kemampuan merencanakan program belajar-mengajar, kemampuan melaksanakan interaksi atau mengelola proses belajarmengajar, dan kemampuan melakukan penilaian (Depdiknas, 2004). Sedangkan Janawi (2011), menjelaskan dimana kompetensi pedagogik adalah kemampuan guru berkenaan dengan penguasaan teoritis dan proses aplikasinya dalam pembelajaran.

Oleh sebab itu, materi pertama yang dilaksanakan dalam kegiatan ini adalah penyusunan perangkat pembelajaran abad 21 berbasis merdeka belajar (one page). Tujuan dari materi ini adalah sebagian besar guruguru di Kabupaten Pelalawan bisa memahami dan menyusun/merancang perangkat pembelajaran abad 21 berbasis merdeka belajar sebagai bentuk perbaikan pembelajaran di sekolah. Materi selanjutnya berkaitan dengan penyusunan bahan ajar, media pembelajaran, lembar kerja peserta didik, dan evaluasi pembelajaran. Semua materi diberikan dalam bentuk sharing knowledge dan diskusi, yang selanjutnya dilakukan penugasan kepada guru dan praktik di lapangan agar para guru tidak sekedar paham teori tetapi juga bisa mempraktekkannya. 


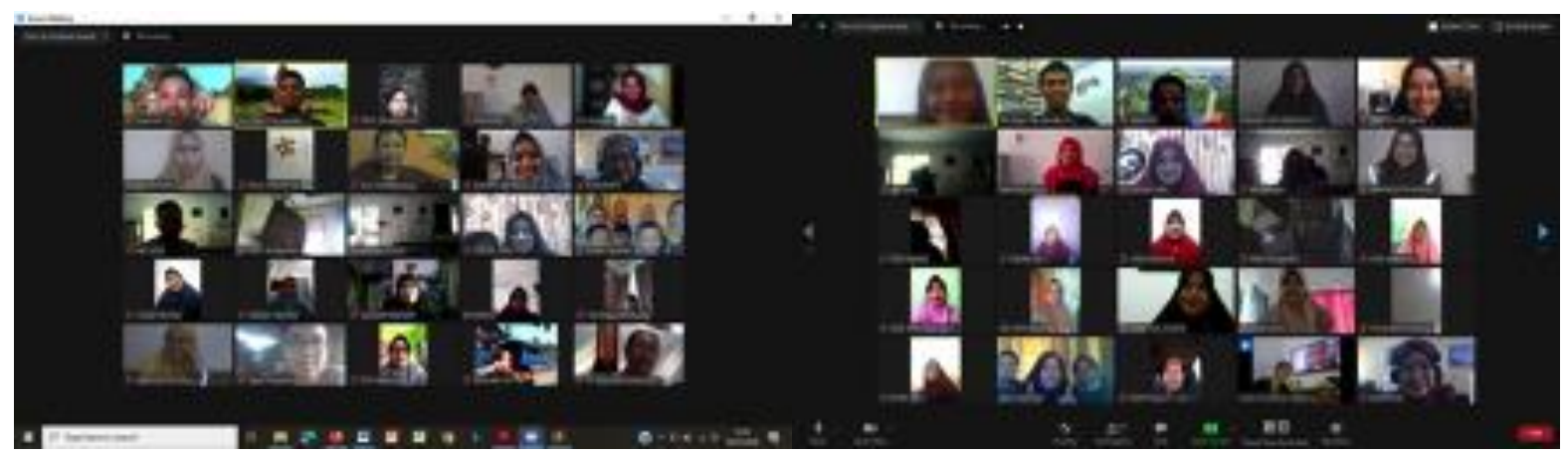

Gambar 2. Kegiatan Pengabdian dengan Zoom Meeting

Kegiatan pengabdian dengan Zoom Meeting ini dilakukan sebanyak 2 kali menggunakan aplikasi Zoom yang diikuti oleh 95 peserta terdiri dari 70 peserta berasal dari Pelalawan dan 35 peserta terbuka bagi masyarakat umum. Kegiatan webinar ini dilakukan mengingat situasi saat pandemic covid-19 belum memungkinkan kita untuk melakukan pelatihan secara langsung. Maka solusi yang terbaik saat itu adalah pelatihan yang berbasis daring (online). Pada webinar 1, narasumber yang memberikan pelatihan adalah Dra. Raminis, M.Pd (Ketua Umum FOGIPSI Riau, sekaligus Guru SMPN 1 Sungai Lala, Pelalawan), Supentri, M.Pd (Dosen UNRI, sekaligus tim pengabdian), dan Piki Setri Pernantah, M.Pd (Dosen UNRI, sekaligus tim pengabdian). Sedangkan pada saat Webinar 2, narasumber yang memberikan pelatihan adalah Dr. Eni Kuswati, M.Pd (Ketua Umum FOGIPSI Pusat, sekaligus Guru SMPN 2 Kudus, Jawa Tengah), Dr. Ahmal, S.Pd., M.Hum (Dosen UNRI, sekaligus tim pengabdian), Mirza Hardian, M.Pd (Dosen UNRI, sekaligus tim pengabdian).

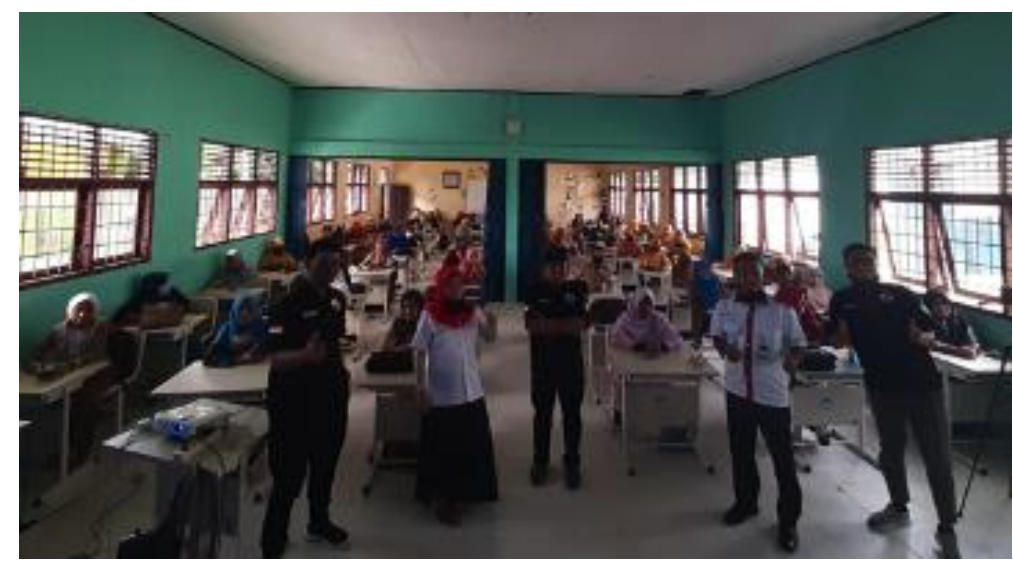

Gambar 3. Kegiatan Pengabdian di Lapangan

Setelah melakukan pengabdian secara daring sebanyak 2 kali dan telah menyampaikan konsep, penguatan, dan praktik. Para peserta selepas daring diberikan penugasan dan dicek pada saat pelatihan langsung. Mengingat situasi lapangan di Kabupaten Pelalawan cukup kondusif saat itu maka sangat perlu rasanya memang melaksanakan pelatihans secara langsung agar dapat praktik langsung dan ketercapaian pengabdian dapat dilaksanakan secara lebih maksimal. Tentu pelaksanaan kegiatan pelatihan langsung yang diadakan di SMAN 1 Pangkalan Kuras ini dilaksanakan dengan standard protocol kesehatan COVID-19, yakni memakai masker, mengatur jarak, dan pemberian hand sanitizer yang turut didukung oleh mahasiswa Kukerta Terintegrasi Abdimas. Pada saat kegiatan lapangan para narasumber dilakukan oleh semua tim pengabdian dan ada bu Dra. Raminis, M.Pd turut hadir menjadi narasumber, sebagai bagian bentuk kerjasama juga dengan organisasi berbadan hukum (FOGIPSI).

Ketercapaian target kegiatan Pengabdian kepada Masyarakat ini secara garis besar mencakup beberapa komponen sebagai berikut:

1) Keberhasilan target jumlah peserta pelatihan

Dari ketercapaian target peserta, kegiatan ini sangat mencapai target peserta, karena webinar 1 dan webinar 2 peserta hadir di atas target 75 peserta, yakni hadir sebanyak 95 peserta. Sedangkan pada saat 
kegiatan pelatihan di lapangan kita targetkan hanya 50 peserta tetapi hadir sebanyak 70 peserta dari para guru se-Kabupaten Pelalawan.

2) Ketercapaian tujuan pelatihan

Tujuan pelatihan ini juga tercapai yakni memberikan pemahaman konsep dan praktis terkait perangkat pembelajaran berbasis merdeka belajar.

3) Ketercapaian target materi yang telah direncanakan

Materi yang disampaikan dalam pelatihan ini juga sangat komplit memberikan pemahaman tentang seluruh komponen yang ada dalam perangkat pembelajaran, malah dalam pelatihan ini ada bonus materi lain yakni tentang Hybrid Learning dan PJJ karena menyesuaikan dengan kondisi covid-19 yang memiliki tren belajar dalam bentuk daring (online).

4) Kemampuan peserta dalam penguasaan materi

Awalnya peserta banyak tidak memahami konsep merdeka belajar dan perangkat pembelajaran berbasis merdeka belajar (disesuaikan dengan ide penyederhanaan RPP dan pembelajaran abad-21). Setelah mengikuti pelatihan pengabdian ini, peserta tidak hanya bertambah dari sisi pemahaman konsep tetapi juga tataran praktik karena juga ada penugasan dan praktik langsung dalam pelatihan ini.

\section{KESIMPULAN}

Program pengabdian kepada masyarakat ini dapat diselenggarakan dengan baik dan berjalan dengan lancar sesuai dengan rencana kegiatan yang telah disusun meskipun terjadi sedikit perubahan jadwal dan format kegiatan dengan menyesuaikan situasi dan kondisi masa covid-19 ini. Kegiatan ini mendapat sambutan sangat baik dari para peserta dan pihak-pihak yang terlibat dalam kegiatan pengabdian ini, terbukti dengan keaktifan peserta mengikuti pendampingan dengan antusias meskipun dalam masa Covid-19 dan tidak meninggalkan tempat sebelum waktu pelatihan berakhir. Dengan adanya pandemic Covid-19 ini kegiatan pengabdian di lapangan hanya bisa berjalan satu kali, sehingga kedepannya diharapkan pelatihan ini dapat berkali-kali diadakan secara langsung agar lebih memantapkan pemahaman guru dalam penyusunan perangkat merdeka belajar dalam mendukung perbaikan dan peningkatan proses belajar di sekolah pada masa sekarang ini.

\section{UCAPAN TERIMA KASIH}

Terima kasih tim pengabdi ucapkan kepada LPPM Universitas Riau selaku pemberi dana kegiatan ini melalui perjanjian kontrak kerjasama Nomor: 857/UN.19.5.1.3/PT.01.03/2020, kepada FOGIPSI selaku mitra kerjasama dengan bukti Surat Bermitra Nomor: 005/SN/Fogipsi Pusat/VI/2020, kepada SMAN 1 Pangkalan Kuras selaku mitra yang menyediakan tempat kegiatan pengabdian di lapangan, dan seluruh pihak yang terlibat dalam kegiatan ini.

\section{DAFTAR PUSTAKA}

Dego, A., Santie, Y., Deehop, S., \& Kerebungu, F. 2019. Analisis Kompetensi Pedagogik Guru IPS di SMP Negeri 1 Kabupaten Pulau Morotai. Jurnal Socius: Journal of Sociology Research and Education, 6(2), 81-89. https://doi.org/10.24036/scs.v6i2.151

Depdiknas. 2004. Petunjuk Pengelolaan Administrasi Sekolah Dasar. Jakarta: Depdiknas.

Janawi. 2011. Kompetensi Guru Citra Guru Profesional. Bandung: Alfabeta.

Kemendikbud. 2019. Merdeka Belajar: Pokok-Pokok Kebijakan Merdeka Belajar. Jakarta: Makalah Rapat Koordinasi Kepala Dinas Pendidikan Seluruh Indonesia.

Ledward, B. C., and D. Hirata. 2011. An overview of 21st century skills. Summary of 21st Century Skills for Students and Teachers, by Pacific Policy Research Center. Honolulu: Kamehameha Schools-Research \& Evaluation.

Mustaghfiroh, Siti. 2020. Konsep Merdeka BelajarPerspektif Aliran Progresivisme John Dewey. Jurnal Studi Guru dan Pembelajaran, 3(1), 141-147. https://doi.org/10.30605/jsgp.3.1.2020.248

Rukayah. 2018. Peningkatan Kompetensi Guru Dalam Perencanaan Pembelajaran Tematik Melalui Supervisi Kelompok Pendekatan Kolaboratif. Jurnal Manajemen Pendidikan Magister Manajemen Pendidikan FKIP Universitas Kristen Satya Wacana, 5(10), 37-46.

Surat Edaran Nomor 14 tahun 2019 Tentang Penyederhanaan Rencana Pelaksanaan Pembelajaran. 
Tilaar, H.A.R. 1998. Manajemen Pendidikan Nasional: Kajian Pendidikan Masa Depan. Bandung: Remaja Rosdakarya.

Trilling, B. and Fadel, C. 2009. 21st Century Skills: Learning for Life in Our Times. San Francisco, Calif., JosseyBass/John Wiley \& Sons, Inc.

Undang-Undang No. 20 Tahun 2003 tentang Sistem Pendidikan Nasional

Yamin, Muhammad \& Syahrir. 2020. Pembangunan Pendidikan Merdeka Belajar (Telaah Metode Pembelajaran). Jurnal Ilmiah Mandala Education, 6(1), 126-136. https://doi.org/10.36312/jime.v6i1.1121 